Huseby-Darvas, Éva V. "Extra Hungariam Non Est Vita? The Relationships between Hungarian Immigrants and Their Homeland." AHEA: E-journal of the American Hungarian Educators Association, Volume 5 (2012): http://ahea.net/e-journal/volume-5-2012

\title{
Extra Hungariam Non Est Vita? The Relationships between Hungarian Immigrants and Their Homeland ${ }^{1}$
}

\section{Éva V. Huseby-Darvas}

Abstract: This study examines various ideologies and myths immigrants hold about their homeland, then turns to look at the relationship over time between immigrants and their natal Hungary. First it explores massive emigrations and minimal remigrations from the AustroHungarian Monarchy during the late $19^{\text {th }}$ and early $20^{\text {th }}$ centuries. While it is impossible to sharply divide economic push factors from political ones, the motivations to leave Hungary were primarily economic in that time. Then I turn to three periods: migrations during the era between the two World Wars; immediately after the Second World War; and to the socialist regime between 1948 and 1989. These times the push factors were mainly political. Finally, I pay attention to the first dozen years of the post-socialist period when emigration was, once again, mainly economically motivated, and remigrations were frequent particularly, though not only, for retirees. (As the study that follows the present one will illustrate, since the Fall of 2010along with global economic problems-political factors, generally low morale, lack of trust in a viable future are major factors once again for the massive outmigration). The immigrants' ties with the homeland changed through time depending not on the intentions of the individuals, but on global politics, and the transformation of the various regimes in Hungary. I discuss some versions of both virtual and actual homecoming, as well as expressions and meanings of long distance nationalism.

Keywords: Hungarian migrations, virtual and actual homecomings, ideologies and myths, long distance nationalism

Biography: Éva V. Huseby-Darvas received her M.A. and Ph.D. in Anthropology at the University of Michigan-Ann Arbor. She has taught part time at the University of MichiganDearborn and Ann Arbor campuses and at E.L.T.E. in Budapest. Her areas of scholarly interest

\footnotetext{
1 This article, reproduced here for its importance to the theme of our Cluster, was originally published in Homecomings: Unsettling Paths of Return. Fran Markowitz \& Anders H. Stefansson Eds. Oxford: Lexington Books, 2004: 76-90. The complete maim of the title, the original source of which is unknown, reads "Extra Hungariam non est vita - Si est vita, non est ita" [Outside of Hungary there is no life - And if there is [life], it is not the same]. This couplet is in a collection of folk proverbs edited by Hans Walther (1965-83). The only source there cited, however, is another collection, indicating that this is just a popular saying not traceable to a specific source.

This study is based on fieldwork among Hungarian immigrants and their offspring in North America that began in 1978 and has continued ever since. First I participated in an NEH-supported project led by Professor Béla Máday in which we collected 150 life histories as part of Project ÁMEN (Hungarian acronym for the Ethnography of American Hungarians). Then I worked in a bi-national project of the American Council of Learned Societies and the Hungarian Academy of Sciences that was led by Professors Linda Dégh and Tamás Hofer; and I also did fieldwork that was supported by the University of Michigan Alcohol Research Center's grant No. P50-AA07378. The generous assistance of these institutions is most appreciated.
}

Acknowledgements: Discussions with friends and colleagues, Noémi Barabás, György Csepeli, Krisztina Fehérváry, Miklós Kontra, Zsolt Lavicza, and István Mikó, who helped with many difficult issues in this paper. I am most thankful to Fran Markowitz and Anders Stefansson who painstakingly read several drafts and patiently made invaluable suggestions. 
Huseby-Darvas, Éva V. "Extra Hungariam Non Est Vita? The Relationships between Hungarian Immigrants and Their Homeland." AHEA: E-journal of the American Hungarian Educators Association, Volume 5 (2012): http://ahea.net/e-journal/volume-5-2012

include looking at the relationship between identity and radical social change and the ramification of migration on gender. Specifically, she has published some fifty articles on East Central European culture and society, kinship networks and gender politics, and the regional development of nationalism and ethnicity, refugees, migrants, and immigrants. She has also published Hungarians in Michigan (2003). In recognition of her research in contributing to the understanding of Hungarian historical, cultural and social development in the homeland and abroad, as well as for her continuous efforts in promoting research cooperation between the U.S. and Hungary, in 2008 Huseby-Darvas was awarded the Knight's Cross Order of Merit of the Republic of Hungary.

According to the often-quoted maxim "extra Hungariam non est vita", or, outside of Hungary there is no life. ${ }^{i}$ Ever since the late nineteenth century, however, many Hungarians indeed have lived outside of Hungary. About a million and half people emigrated from just the Hungarian part of the Austro-Hungarian Monarchy between the 1880s and the outbreak of World War One, causing what contemporary observers called a "social and psychological upheaval in the country" (Frank 1999:134). We do not know the exact number of those who returned permanently; the rough estimate is anywhere between 16 and 30 percent. A popular saying at the time was that rather than coming back with wealth, "the returnees from America brought home glaucoma and weird religious sects." Though several pragmatic students of contemporary Hungarian society called emigration a much-needed safety valve, it evoked immensely negative public and political opinion in the nation whose "solemn sustaining myths [included]... a stubborn isolation of a Godgiven separate identity...an irrepressible yearning for a return to the grandeur of ancient virtues, and a quixotic predilection to live in the alternative reality of a mythic past" (Fenyvesi 2003:20).

Of course, neither such myths nor the accompanying ideology stopped emigration, though the motivations, the push factors to leave the country changed from one emigrant wave to the other. The immigration laws instituted in 1924 in the U.S. radically slowed down immigration but did not stop it. Instead, they changed the emigrants' destination to Canada, Australia and South America. Emigration did not stop at the turn of the twentieth century either when a "million and a half of ...people staggered out to America" (József 1937). Rather, it continued throughout much of the twentieth century. People left during and past the years of goulash communism, as the period between 1968 and 1989 was called in Hungary. Goulash communism contained less rigid central planning and offered more economical freedom, and considerably more consumer goods than did other countries in the Soviet bloc.

Unlike the economically motivated, mostly rural emigrants who left Hungary during the late nineteenth and early twentieth centuries, later emigrants left mainly for political reasons. These include the people who left in between the two world wars, as well as the many Displaced Persons (DPs) who left after World War II and were mainly urban, professional and educated. So too were the approximately 200,000 ' 56 ers who fled their homeland after the revolution of 1956, although they hailed from both rural and urban Hungary. Tens of thousands of ethnic Hungarians who left their homeland after the 1970s usually offered political motivations as well.

Like many other immigrants and refugees (see Anderson 1983, 1992; Kearney 1986; Safran 1991; Said 1992; Trix 2001; Tsuda 2000), the majority of Hungarians also maintained ties with their homeland, though the nature and intensity of these ties depended on, among other things, the global politics of the times. For example, during the two World Wars and in part of the 
Huseby-Darvas, Éva V. "Extra Hungariam Non Est Vita? The Relationships between Hungarian Immigrants and Their Homeland." AHEA: E-journal of the American Hungarian Educators Association, Volume 5 (2012): http://ahea.net/e-journal/volume-5-2012

period between 1948 and 1989 the relationship between immigrants and the homeland was limited at best, and almost non-existent at worse.

Since push and pull factors were more or less similar within each distinct group, Hungarians tend to stratify according to when they left their homeland, what kinds of ideological baggage they carried with them, and when they arrived in North America. These factors seem to be critical in understanding the various groups' different images and notions about and relationships and attachments to their homeland and therefore directly relevant to the meanings of homecoming.

The end of communism following the annus mirabilis of 1989 inspired some HungarianAmericans to remigrate, and many more to visit their homeland. There are perhaps as many different types of homecomings as there are remigrants and those who dream of returning to their natal land. My concern in the first part of this chapter is with the homecomings of political émigrés. Their homecomings are often virtual: they are yearned for, frequently discussed, but seldom physically carried out. In other words, I probe the question: Why did so few of those émigrés who declared for many decades and keep declaring that they left their "beloved homeland just to escape communism" move back there since 1989 when the regime changed?

When immigrants and refugees did return to Hungary, the country that they found bore little resemblance to the place of their dreams. Instead of the imagined homeland and the crucial roles that they would play in it, the returnees found poverty and troublesome shadows of past regimes. For their part, the "natives," those who had remained in Hungary, perceived the returnees as strangers who were unable to understand contemporary Hungarian ways and often rejected the western expertise that the returnees were so eager to offer. Thus, instead of the warm homecoming imagined by the émigrés, they often descended into an abyss of mutual misunderstanding with their Hungarian counterparts (see also Kundera 2001; Stefansson, this volume).

The chapter first contrasts an example of virtual homecoming by those who practice what Benedict Anderson (1992) calls long-distance nationalism and achieve a sense of return without actually moving from their adopted homes in North America to those who do return and import long-distance nationalism. The discussion then moves to less politically motivated returns, those connected to lifecycle passages - retirement homecomings and the "return" of children and grandchildren of immigrants via academic and investment programs, heritage and "roots" tours. I round out this discussion by describing what can be called the ultimate homecoming, the return of the dead to the sacred soil of the motherland. Then, on a critical note, I offer a brief presentation of the theme of homecomings as it appears in contemporary Hungarian and American-Hungarian performing arts. Finally, dusting off an old cliché, I suggest that in cases where the imagined place and expectations on the one hand, and the actual site and the realities of (un)welcome on the other clash so sharply in people's experience, one can never really go home again.

\section{Types of Homecomings: The Virtual Homecoming of Long Distance Nationals}

In what Viktor Frankl (2000) called "man's eternal search for meaning" the importance of long-distance nationalism or diaspora nationalism for many immigrants cannot be overstated. Since the late 1970s I have found this to be the case over and again. I was often surprised, however, to see that long-distance nationalism among Hungarian-Americans cuts across class 
Huseby-Darvas, Éva V. "Extra Hungariam Non Est Vita? The Relationships between Hungarian Immigrants and Their Homeland." AHEA: E-journal of the American Hungarian Educators Association, Volume 5 (2012): http://ahea.net/e-journal/volume-5-2012

lines but not gender divisions. Just as Benedict Anderson has noted, it appears to be entirely a male domain.

The following excerpts are from my fieldnotes of March, 1994:

For the 1994 commemoration of the Hungarian Revolution of 1848, there were about 120 people in the Michigan church's social hall where these events are usually held. In the audience there were more men present than women; mostly middle aged or older folks and just a few young people and children. All participants were dressed in their Sunday best, and were wearing the traditional red-white-and-green cockade, the Hungarian colors and symbol, on the left side...During this observance, a clergyman - a very popular individual, who is greatly admired by members of his congregation - gave the main address. Among other things, he said,

"We, who gathered here, believe in a szebb, jobb, magyarabb (a lovelier, better, more Hungarian) future... Our task is to remember and to remind! We should dare to be Hungarians! We, here, are deeply concerned about the fate of our beloved homeland. Thus we must teach those who are at home! For the sake of a happier Hungarian future of all Hungarians: at home, abroad, and on the dismembered territories [az elszakitott területeken]...The fight today [the time reference was to the upcoming 1994 elections in Hungary] is a life and death struggle... We protest while raising our voices against the internal and external enemies of our homeland! Hungary is for the Hungarians! 'Each Hungarian,' if I may quote István Csurka, 'must be tested for their Hungarianness!' What does it mean to be a Hungarian today? It means to take our responsibility for our common destiny. We do not want to be different from our forefathers! Was there really a true change of regime in the past four years in Hungary? Can Hungarian mothers be proud, once again? Sadly, the answer is No! The internal and external enemies are still at work against our nation....It is our responsibility to help our people to find the way, the way of justice and truth... A nation dies not when it is subjected to outside tyranny, but when it forgets its national calling and mission.... we are here to remember and remind...." [all translation is mine].

His concluding remarks reminded the audience that, "It is our responsibility [here] to write to our kin, friends, former neighbors and tell them to cast their votes for the [individual and Party that] will make...the Hungarian mothers once again proud."

This vignette represents, I believe, a classic case of long-distance nationalism. The clergyman's address legitimates not returning permanently to Hungary because the diaspora possesses a kind of insight and impact that is lacking among the natives in the homeland. It is a kind of virtual homecoming, one where actually moving from the U.S. is replaced by an ideological springboard for remaining abroad to actively shape Hungary's contemporary political events and the future of the homeland. 
Huseby-Darvas, Éva V. "Extra Hungariam Non Est Vita? The Relationships between Hungarian Immigrants and Their Homeland." AHEA: E-journal of the American Hungarian Educators Association, Volume 5 (2012): http://ahea.net/e-journal/volume-5-2012

\section{Actual Homecomings: Importing Long Distance Nationalism}

The following homecoming examples demonstrate the imported long-distance nationalism of émigrés who actually return to pursue a definite political agenda. These returnees are zealous, often fanatical, and do not ask if their beliefs, teachings and actions are appropriate for contemporary Hungary. The cases of Albert Szabó and István Porubszky show what happens when, after decades as immigrants, individuals inspired by atavistic ideology return to the homeland. Szabó, an immigrant in Australia, returned to Hungary in the early 1990s and organized a neo-Nazi party that was explicitly modeled after Ferenc Szálasi's fascist Arrow Cross Party. Szálasi, this Nazi German-aligned party's leader, was put in power in October 1944 at Hitler's order (Hockenos 1993:155). After Szabó's neo-Nazi party was outlawed, he founded another one, this time innocently-named the Hungarian People's Welfare Federation.

During the 1990s, Szabó was arrested several times for using Nazi emblems, and for "incitement against a community". In 1996 during a rally for the 1956 Hungarian Revolution he called for the resettlement of Hungary's Jews in Israel. A day later, the presidium of István Csurka's far-right Hungarian Justice and Life Party disassociated itself from Szabó and asked the police to keep both him and his associates away from its gathering. Later in the decade Albert Szabó left Hungary and rumor has it that he returned to Australia. According to members of his organization Szabó only left temporarily to get financial support for his party, and his plan is to re-return to the Hungarian homeland.

István Porubszky's actions can be seen in a similar vein, yet, since he has been organizing and "educating" teenage youth in Hungary, his actions may very likely yield more far-reaching results than those of Szabó. Porubszky fled Hungary after the Revolution of 1956 in which it is said that he fought and returned from Canada to his homeland in the late 1980s. Shortly thereafter he became the leader of the 1956 Anti-Fascist and Anti-Bolshevik Association, which, among other things, trains skinheads in right-wing philosophy, and gathers teenage youth into a group called the National Conservative-Thinking Boys. These young men, who affectionately call and refer to Porubszky as Potyka bácsi or Uncle Potyka, listen to lectures on a particular version of Hungarian history, celebrate the mythical Turul bird, a symbol of national unity, and demand the overturn of the 1920 Trianon Treaty that dismembered the Hungarian motherland.

It is one of the many ironies of post-1989 Hungary that while Albert Szabó was officially criticized and arrested for some of his actions, Porubszky was given a hero's medal for his in 1998, much to the eventual embarrassment and explicit public apologies of members of the government. These government figures claimed that the medal and accolades were conferred because of Porubszky's heroism in the 1956 Revolution, and that they were unaware of his political activities in Hungary after his return from Canada.

Of course the majority of returnees or would-be-returnees to Hungary is far from the aforementioned extremes. Motivations to return home or to stay away rarely revolve around political factors. More frequently the dilemma of returning from or staying in the West is determined by personal or familial circumstances; in particular, children, grandchildren and valued social relations with special friends and neighbors in current living places as well as the difficulties of travel and being away from comfort are mentioned from time to time as the key factors for not returning. Still, ambivalence lingers especially in view of some attractivesounding offers by the Hungarian state to those who return and resettle there. 
Huseby-Darvas, Éva V. "Extra Hungariam Non Est Vita? The Relationships between Hungarian Immigrants and Their Homeland." AHEA: E-journal of the American Hungarian Educators Association, Volume 5 (2012): http://ahea.net/e-journal/volume-5-2012

\section{Hazacsalogatók: Soliciting the Return of Retired and Other Immigrants}

A clearly stated intent of the Hungarian government and private entrepreneurs alike is to attract more and more investors from among the various overseas Hungarians, especially North Americans. The number of visitors to Hungary from the United States annually was 220,000 in 1990, 358,000 in 1998, and 356,000 in 2000 (MSZs 2001:269). A large portion of these visitors are immigrants and their children and grandchildren. The Hungarian state makes serious and often successful attempts to encourage immigrants to visit and consider resettling in the homeland. At the risk of sounding cynical, these attempts are designed to attract some Western capital, if not always the actual bodies, to come home. Particularly in the last decades various attempts have been made to reach out to immigrants in the West and make it increasingly appealing for them to set up a second residence and invest in Hungary. Just since January 2000 alone, $\$ 600$ million was invested in hotels and hotel improvements, primarily by American and American Hungarian investors. The solicitations via various forms of media, websites, embassy programs, and by Hungarian delegations visiting larger immigrant communities are what some Hungarians in North America facetiously, and at times dismissively, call hazacsalogatók, which roughly translates as temptations to return.

Some programs attempt to awaken a general interest in Hungary. For example the program called "Routes to your Roots: Hungarian Heritage Tours" is clearly intended for immigrants of just about any age and their offspring. The organizers include in these tours individualized trips to the visitors' own or ancestral settlements where they may be encouraged to help the local churches, schools, or invest outright in an economic venture. The travelers and investors are also led to various websites where they can do research on their families' "roots." Creating a concerned diaspora and potential homecomers via academic programs and heritage tours is also an aim of the Hungarian state. Several universities and other institutes, such as the recently founded Bálint Balassi School, organize youth and language programs that, judging from the curriculum, are aimed particularly at the offspring of immigrants. The curriculum does not deal as much with Hungarian culture and society as it focuses on Hungarian immigration through the ages. It poignantly concludes with a unit on "The future of immigrants and the responsibility of immigrant communities."

Numerous solicitations appeal to elderly immigrants, in particular a type of medical tourism. Dental, medical, and spa tours are offered, still fairly reasonably priced package deals for retired, aging immigrants. While the prices charged for them are higher than those for "natives," these are still much less expensive than similar medical services in the West. Another attempt is contacting elderly immigrants who are either retired or getting ready to retire and encourage them to return and resettle in Hungary. Many elderly folks often revert to the language of their formative years and forget all or parts of their adopted language (Nóra Arató, personal communication), and for these pensioners, returning to Hungary can be an economically sound step in addition to an emotionally rewarding one. Even though the cost of living has been continuously increasing as Hungary prepares to join the European Union (MSZs 2001:189-209), most retired folks realize that their U.S. retirement pensions go much further in Hungary and can even provide them with elements of luxury.

One retirement home, the Arany Alkony Otthon, or the Golden Dusk Home, makes remarkable use of language in its advertisements that appeal to potential homecomers. These are carefully composed appeals that are nostalgia-evoking on the one hand, and pragmatic-sounding on the other. It promises elderly immigrants that heeding the beckoning of the Nagy Visszatérés 
Huseby-Darvas, Éva V. "Extra Hungariam Non Est Vita? The Relationships between Hungarian Immigrants and Their Homeland." AHEA: E-journal of the American Hungarian Educators Association, Volume 5 (2012): http://ahea.net/e-journal/volume-5-2012

Periódusa, or the "period of great return" will richly pay off (see also Kundera 2001:6 for nearly the same phrase). They will, once again, feel the spirit of the beauty of their childhood and youth while, at the same time, they will live out the rest of their days comfortably and content, "on Hungarian soil, amid Hungarians [the ads refer to other actual and also potential owners in the Golden Dusk Home as "members of the Hungarian upper and upper-middle class"], surrounded by their own people and speak their own mother-tongue, the unique and beautiful Hungarian language". All this, and the promise of security, safety, luxury, privacy, independent living, as the advertisers state, will allow the returnees to enjoy the good life of a solid "Western life style." However, for those immigrants who do not take advantage of these and similar tempting offers, but go gently (or otherwise) into the night in the U.S., there remain various opportunities for going home after they breathe their last breath.

\section{Homecoming in Death?}

A number of poignant works deal with explicitly politically motivated (re)burials of refugees, émigrés, immigrants (in addition to Holsey, this volume, see also Gal 1991; Rév 1995; Verdery 1999; Zempléni 2003). The interment of immigrants in Hungarian soil (one way or another), is not only the definitive, final homecoming, but also a political statement of those family members who insist on it.

Shortly before his premature death Attila József (1937/b) wrote in a poem entitled "Homeland"

And so I've found my native country, / that soil the gravedigger will frame, / where they who write the words above me / do not for once misspell my name...

These lines reverberated in my mind each time I attended the funeral of Hungarian-American acquaintances. After one such event in July of 1988 I realized that the funeral portrayed a type of homecoming after death - without leaving the U.S.:

We attended the open-casket visitation... then the actual burial the day after... [his older sister] Julia, hailing from rural Hungary, who could not get a flight out earlier, just arrived in Michigan on the morning of the [56er's] funeral. At the grave she took a crumpled silver ribbon off a redwhite-and-green box and, disregarding the "proper" order, went ahead of the [widow] and the kids ...to the grave [...], she reached into the box and slowly poured handfuls of what looked like brown dust on top of the lowered casket.... Later, back at the house during the wake while expressing my condolences to members of the family, I asked Julia [known for her fine embroidery work], to tell me about her trip and what she had brought with her at this sad time. After a while she said "Look, Öcsi [nickname, referring to or addressing a younger brother] would never be in peace in foreign soil. Just could not rest. He must have had a premonition a couple of weeks ago. He called and asked to bring him some earth from our [family] orchard. So now that is all I brought." 
Huseby-Darvas, Éva V. "Extra Hungariam Non Est Vita? The Relationships between Hungarian Immigrants and Their Homeland." AHEA: E-journal of the American Hungarian Educators Association, Volume 5 (2012): http://ahea.net/e-journal/volume-5-2012

In a sense placing Hungarian soil, particularly from the family's homestead, in the grave that is in the U.S. legitimizes staying abroad while maintaining Hungarian ties. But shipping bodies or ashes back to be buried in Hungary is, I contend, the ultimate homecoming.

A retired Ford Motor Company assembly-line worker, a 56er, insisted that his wife's body be taken back to Hungary. This was a costly affair that required more money than he could easily afford. After battling with his children, who did not understand why he insisted on this overseas burial, and with bureaucracy on both sides of the Ocean, he succeeded in having her buried in her natal small town beside their kin. For this Hungarian American it was of crucial importance that his wife be "reunited" with her family. I have often been given additional explanations, such as to rest in "sacred home soil", or "sleep his eternal sleep" next to long-dead family members, or simply to place "his bones where he belongs."

In several cases only the ashes of immigrants were returned to Hungary and buried in private rites of passage in family plots. In one particular instance, although cremation was against the religion of the family, a middle-aged 56-er university professor brought his mother's ashes back to Budapest. He took a small toy shovel to the cemetery and in a very private ceremony attended by only two people buried the ashes alongside of his long-deceased father's grave. The reason he gave me was that "you know that she was left as a widow [46 years before]. Mother never remarried. It gives me a kind of peace of mind to reunite them once more." He hired one of the cemetery workers on the spot and had his mother's names engraved in gold letters on the black granite headstone of his father. Her long name, with all the correct diacritical marks in place, was, finally, not misspelled.

\section{Critiques of Homecomings: Artists Leery of Homecomings}

From the considerable variety of critiques of homecoming to Hungary two stand out as culturally salient and politically provocative. The first is a group of artistic productions that cast the issue of homecoming in sharp relief as they ponder and reflect, ridicule and toy with the relationship between natives and immigrants. The second is the continuing social process of emigration from Hungary to North America, expressing the desire of individuals seeking more fruitful homes than the one offered by the homeland.

The reality of possible remigration with all its ambivalence, implications and effects became a hot topic since the fall of the "Iron Curtain" in 1989. Besides exerting its presence in economic and political arenas, remigration has surfaced as a central theme in literature, the cinema and theater. A key example György Spiró's 1996 play, Kvartett [“Quartet”], which was made into a movie a year after its initial stage production. "Quartet" continues to be successful both in Hungarian theaters and in numerous immigrant cultural centers as it portrays an encounter between two worlds. After 40-some years an immigrant returns to Budapest from the U.S. just to reunite with the man who saved his life during the revolution of 1956 and to shower his savior with everything that money can buy. The much-awaited and highly anticipated return results in misunderstanding; it is a total fiasco. Very different sets of values, world views, ideologies and beliefs emerge, meet and clash. After both sides register disillusionment, the "native" is frustrated, angry, and accusatory, while the immigrant realizes that his homeland is no longer his home, and departs for the United States - finally, it can be presumed. The abyss between the returnee and those who stayed at home is portrayed as unbridgeable (cf. Kundera 2001). 
Huseby-Darvas, Éva V. "Extra Hungariam Non Est Vita? The Relationships between Hungarian Immigrants and Their Homeland." AHEA: E-journal of the American Hungarian Educators Association, Volume 5 (2012): http://ahea.net/e-journal/volume-5-2012

The 2001 low-budget Hungarian comedy entitled, Valami Amerika ["Some America"] unexpectedly became one of the most popular films of recent years in Hungary and was also shown in a number of immigrant communities in the West. It is about a returnee, who calls himself Alex Bruebaker, and as viewers are informed at the beginning of the film when he enters the country from Austria, driving a large, unusually luxurious car while puffing on a large, presumably expensive cigar, waited for many years to go back home, taste familiar foods and see beloved sites. This scene implies that he is hoping for the warmth of home, though without giving himself away, without telling anyone that he is originally from Hungary, while three brothers in Budapest are eagerly waiting for him, plotting and scheming in expectation that that he will solve their financial difficulty. Valami Amerika ends by revealing that Alex, the returnee, is a liar who hides his true identity from the brothers by pretending to be an American film producer with money to invest, and pretending not to understand any Hungarian. He is really a returning emigrant who is still fluent in the language and thus understands every word that the brothers say about him and their plans. Alex paradoxically turns out to be a thief who disappears with what little money the brothers have and takes away one of their girlfriends.

Both films are thought-provoking critiques of homecoming. In "Quartet" Spíró's main question is: how could one go home again, when an immigrant's expectations and hopes are so distorted by memories that they can not even be comprehended by the people in the homeland? The message in "Some America" is that both natives and homecomers scheme shamelessly to take advantage of the other.

"An American Rhapsody" is an autobiographical film written and directed by the HungarianAmerican Éva Gárdos. It deals with identity crises, loss, disappointment, and cross-cultural and cross-generational miscommunication all embedded in a coming-of-age story. Gárdos' alter-ego, Zsuzsi or Suzanne, has two sets of parents. One resides in a small, quaint Hungarian village where Zsuzsi was raised with much love and warmth until age six. The other set, her biological parents are political refugees who fled Hungary in the early 1950s and lived during the late 1950s and early 1960s in urban Los Angeles where Zsuzsi, who then becomes Suzanne, is sent from Hungary by her maternal grandmother. Suzanne realizes her much-longed-for and dreamt about return to Hungary and reuniting with her dearly loved rural (grand)parents when she is fifteen. In Hungary she comes to understand that she is no longer really home in her homeland as she finally learns about the past, the reasons for her parents' forced emigration and their overprotectiveness in Los Angeles. She returns to the U.S., presumably a calmer, wiser young woman who more or less knows where she belongs.

\section{Disappointment in Homecoming: Desires to Leave the Homeland}

In Taylor, Michigan a 60-year old man just after returning from spending six weeks in the homeland where he had considered resettling, reported, "[in Hungary] the wife and I realized that it is easier to be a Hungarian here, from afar". It was not a joke: when some people smiled he got angry and went into great details about what they experienced during their long visit. Among other things, he said, the young tended to be too cynical; people no longer knew or seemed to care much for their own country's history; even in the countryside almost everything was too westernized. For example, there were too many signs and advertisements, and the people didn't even talk real Hungarian anymore: they used too many English words and often used them incorrectly. Thus, the other critique of the homecoming issue responds to the claim, extra Hungariam non est vita, that in fact there is life outside of Hungary. This critique comes from 
Huseby-Darvas, Éva V. "Extra Hungariam Non Est Vita? The Relationships between Hungarian Immigrants and Their Homeland." AHEA: E-journal of the American Hungarian Educators Association, Volume 5 (2012): http://ahea.net/e-journal/volume-5-2012

those who actually experience that homeland, who return from abroad and come face to face with that much dreamt about land and its people after decades of hoping to return. Many return to North America disappointed, and discuss what they experienced in Hungary, particularly the plight of many young people who cannot find jobs, the struggle of pensioners to make ends meet, and that of the former middle classes who lost their footing and a sense of social security as a result of the radical changes that followed 1989.

A parallel critique is the potential for and actual emigration from Hungary, or brain drain. It is a frequent topic in electronic communications where the frustration and ambivalence of whitecollar technical professionals and others are most evident. For example, in an early April 1995 electronic mail communication one young Hungarian engineer, working in the United States, wrote:

Here it is possible to work, at home it is not! Here you can exist on your income, at home you cannot! / Here there is tolerance, at home [it does not exist]! / Here it counts what you accomplish, at home it does not! / Here it counts what you have accomplished, at home it does not! / Here they appreciate your work, at home they do not! / Here they are not envious, at home they are! Here they use you, at home they exploit you! / Still. Why is it that I only wish to come here for one or two years? Why is it that I want to live at home? I do not know! There is no rational answer. But if they destroy the country, they destroy my life and then I will not think for long [to emigrate permanently].

\section{Conclusion: Is There a Safe Return amid an Abyss of Misunderstandings?}

Immigrants often voice how much they have sacrificed financially and morally for their homeland from afar without mentioning or perhaps even realizing that these actions, whether actual or imagined, gave them good reason for staying away from that home. In spite of mostly good intentions both among Hungarian-American immigrants and Hungarian visitors from the homeland, dialogues between these two groups often appear to be mutually incomprehensible. Neither party seems to listen to the other. There is little, if any, mutual understanding, but considerable aggregate, yet unshared, resentment. The Hungarian-Americans resent that visitors from Hungary refuse to acknowledge their professional and economic accomplishments in the West or their alleged sacrifice for their homeland. Rather, they believe that the Hungarian natives, either openly or furtively, make them feel as traitors who left their homeland and the people there in the lurch after World War II or after the revolution of 1956. The question "How could you?" is always implied, even when not articulated. For their part, the natives, either at home in Hungary or during visits from the homeland, resent what they perceive as the immigrants' condescension and what they often see as the immigrants' being out of touch with Hungarian reality although they talk as if they know it all; moreover many clearly state that they wish to interfere in and profit from Hungary's post-1989 polity and economy.

As this chapter has shown, for many Hungarian immigrants in North America time has stood still ever since they left Hungary. They look at their frozen-in-time natal country through an idealized, romanticized, nostalgic prism that not only distorts the already static image, but makes their image of Hungary more enduring and tantalizing from the distance. While occasional visits in Hungary may somewhat alter this image, the visits do not destroy it. 
Huseby-Darvas, Éva V. "Extra Hungariam Non Est Vita? The Relationships between Hungarian Immigrants and Their Homeland." AHEA: E-journal of the American Hungarian Educators Association, Volume 5 (2012): http://ahea.net/e-journal/volume-5-2012

This chapter has reviewed several types of homecomings while glancing at the state's and entrepreneurs' motivations to encourage return migration and investments. Its major finding is that despite the variety of motivations and returns, and stated desires for one all-encompassing Hungarian identity and homeland, misunderstandings characterize most encounters between returning immigrants and those who stayed at home. Perhaps one reason for this gap lies in the decades-long practice by some immigrants of long-distance nationalism that achieves a sense of return without actually moving, or its parallel manifestation of imported long-distance nationalism by returnees.

Long before the dramatic events of 1989 Iván Sanders (1974:91), with impressive insight wrote that "My experiences led me to the regrettable conclusion that it is not always possible for those Hungarians who live outside of Hungary to get on the same wave length with those from home, even if they really want to get close to one another." Indeed, the relationship between immigrants and those in their homelands is a highly complex, ambivalent, and difficult one and, as I have shown, this adds to the problems and ambiguities of homecomings.

Is there a "safe return," a good homecoming? Can one indeed go home again? I venture to say that a modern-day version of the old, early twentieth century strategy of circular or pendular migration with bi-national residences and jobs, and transnational networks and families would come close to a positive answer for the young, mobile generations as a sort of a homecoming. For those who return with a specific political agenda along with the moral and financial help of far-away immigrant communities, as did Szabó and Porubszky, going home gives a reason for being. However, I would suggest that their return is not really a homecoming; rather it continues the chase after the mythical dreams of long-distance nationalists. For the aging or aged immigrants with dreams about a glorious homecoming and a life of comfort and ease, I would say that the answer is to have enough money when they return to create and maintain an isolated bubble, removed from the contemporary reality of everyday Hungary. The Golden Dusk Home presents an excellent example of this strategy. So too do the handful of individuals I interviewed who bought luxury apartments in secure buildings in relatively quiet and calm provincial cities, and live among, commiserate, and swagger along with fellow returnees.

Let me close with my favorite story of a homecoming dream. While collecting the life histories of elderly Hungarian Americans, one man kept insisting through three long, open-ended interviews that he would never go back to his homeland because, as he informed me coldly and with obvious conviction, "Hungary ceased to exist on the afternoon of December $24^{\text {th }} 1944$ [when he left the country]. It became a Soviet Dominion." Finally, when we got to the last interview I asked him where he would like to be buried. At this point the man, who was extremely polite, elegant, proud, stiff and stoic throughout all our encounters, started to cry and said that he does not want to be buried. Rather, he wants to be cremated and have his ashes scattered here so the wind will take at least parts of him back to his beloved homeland. He died in 2000. I know that his sister had him cremated, but I cannot tell you if his wish came true. 
Huseby-Darvas, Éva V. "Extra Hungariam Non Est Vita? The Relationships between Hungarian Immigrants and Their Homeland." AHEA: E-journal of the American Hungarian Educators Association, Volume 5 (2012): http://ahea.net/e-journal/volume-5-2012

\section{Works Cited}

Anderson, Benedict. 1983. Imagined Communities. London: Verso. . 1992. "Long-Distance Nationalism: World Capitalism and the Rise of Identity

Politics." The New Left Review 193: 3-13. 1994. "Exile." Critical Inquiry 20. 2: 314-327.

Allen, Tim, and Hubert Morsink, eds. 1994. When Refugees Go Home: African Experiences. London: James Currey.

Csepeli, György. 2002. A Nagyvilágon E Kivül... Nemzeti Tudat és Érzésvilág Magyarországon 1970-2002. [Beyond this [Land] in the Whole Wide World...National Awareness and Feeling in Hungary 1970-2002]. Budapest: Jószöveg.

Csepeli, György, and Tibor Závecz. 1992."Conflicting Bonds of Nationality in Hungary. National Identity, Minority Status and Ethnicity. Innovation 5. 2: 77-94.

Deák, István. 1994. "Post-Communist Hungary." 1994. New York Review of Books (August 11: 33-38.

Fenyvesi, Charles. 2003. When Angels Fooled the World: Rescuers of Jews in Wartime Hungary. Madison,: University of Wisconsin Press, 2003.

Frankl, Viktor E. 2000 [1946]. Men's Search for Meaning. New York: Washington Square Press.

Gal, Susan. 1991. "Bartók’s Funeral: Representation of Europe in Hungarian Political Rhetoric." American Ethnologist, Volume 18, Issue 3, pages 440-458, August 1991.

Hockenos, Paul. 1993a. Free to Hate: The Rise of the Right in Post-Communist Eastern Europe. New York and London: Routledge.

1993b. "Racism Unbound in the Land of the Magyars. New Politics 4.2 Winter 1993, 69-81.

Huseby, Éva V. 1984. Community Cohesion and Identity Maintenance in a Hungarian Village. Ph.D. Dissertation. Ann Arbor, MI: University of Michigan. . 2003. Hungarians in Michigan. East Lansing: Michigan State University Press.

Jackson, Michael. 1995. At Home in the World. Durham and London: Duke University Press,. József, Attila. 1937a. Hazám: Összegyüjtött Versek [My Homeland: Collected Poems]. 1997-1998. "Íme, hát megleltem hazámat” [And I Found My Homeland]. The Hungarian Quarterly148-149 (Winter 1997 - Spring 1998[

Kearney, Michael. 1986. "From the Invisible Hand to Visible Feet: Anthropological Studies of Migration and Development. Annual Review of Anthropology 15: 331-361.

Kundera, Milan. 2001. Nemtudás [Ignorance]. Budapest: Európa,.

Lengyel, Emil. 1974 [1948]. Americans from Hungary. Westport, CT: Greenwood Press, Magyar Statisztikai Zsebkönyv (MSZs) 2000. Hungarian Statistical Handbook 2000. Budapest: Hungarian Statistical Office, 2001.

Malkki, Liisa H. 1995. "Refugees and Exile: From 'Refugee Studies' to the National Order of Things." Annual Review of Anthropology 24: 495-523.

Mendoza, Louis and S. Shankar, eds. 2003. Crossing into America: The New Literature of Immigration. New York: New Press. 
Huseby-Darvas, Éva V. "Extra Hungariam Non Est Vita? The Relationships between Hungarian Immigrants and Their Homeland." AHEA: E-journal of the American Hungarian Educators Association, Volume 5 (2012): http://ahea.net/e-journal/volume-5-2012

Nyerges, Anton. 1973. Attila József. (József’s poems translated to English by Anton Nyerges) Volume 47 of Material de lectura: Serie Poesía moderna. Issue 3 of Publication, New York (State). State University College, Buffalo.

Rév, István. 1995. "Parallel Autopsies." Representations 49 (1995): 15-39.

Safran, William. 1991. "Diasporas in Modern Societies: Myths of Homeland and Return." Diaspora 1. 1: 83-99.

Said, Edward. 1002. "Reflections on Exile." Out There: Marginalization and Contemporary Cultures, edited by Russell Ferguson, Martha Gever, Trinh T. Minh-ha and Cornel West, Eds. London: the MIT Press: 357-66.

Sanders, Iván. 1974. "Két világ között: egy amerikai magyar vallomása." [Between Two Worlds: Confession of an American Hungarian]. Valóság 8: 84-94.

Teleky, Richard. 1997. Hungarian Rhapsodies: Essays on Ethnicity, Identity and Culture. Seattle: University of Washington Press.

Trix, Frances. 2001. Albanians in Michigan. East Lansing: Michigan State University Press,. Tsuda, Takeyuki. 2000. "Migration and Alienation: Japanese-Brazilian Return Migrants and the Search for Homeland Abroad." The Center for Comparative Immigration Studies, University of California, Working Paper no. 24.

Várdy, Steven Béla. 1985. The Hungarian Americans. Boston: Twayne Publishers.

Verdery, Katherine. 1999. The Political Lives of Dead Bodies: Reburial and Postsocialist Change. New York: Columbia University Press.

Walter, Hans, editor. 1965-1983. Sententiaeque Proverbia latinitatis Medii aevi. Lateinische Sprichwörter und Sentenzen of Mittelalters in alphabetischer Anordnung. Göttingen. 